【論文】

UDC : $551.55: 697.003 .1: 697.11$
日本建築学会計画系論文報告集

第 381 㤐・昭和 62 年 11 月

\title{
ENERGY SAVINGS OF APARTMENT HOUSES BY NATURAL VENTILATION
}

\author{
by QINGYUAN ZHANG*1), TADAHISA KATAYAMA*21, \\ TETSUO HAYASHI*3), AKIO ISHII*4), MASARU \\ NISHIDA*5), NORIKO SAKAKIBARA*6), and JUN- \\ ICHIRO TSUTSUMI*7), Members of A. I. J.
}

\section{Introduction}

In the hot season, natural ventilation is generally used to cool buildings. Wind takes away the heat from buildings, which is from the solar radiation and generated heat from equipment such as lights, and also removes sensible and latent heat from human bodies, improving the thermal sensation. The utilization of natural ventilation is influenced by many factors such as the daily living schedule of occupants, weather condition of a region, surrounding environments and building design. The purpose of this paper is to analyze quantitatively the energy saving effects by cross-ventilation, relating to the arrangement of apartment buildings and the location of them.

There have been several studies on the natural ventilation of dwellings. The authors have investigated the ventilation and the indoor thermal environment of apartment building from the viewpoint of energy savings ${ }^{1) \sim 4}$. Recently, the natural ventilation of dwellings for the purpose of saving energy is also studied actively in Europe and the United States, and some computations and experiments are reported, such as the papers of Chandra et al. ${ }^{5)}$ and Kammerud et al. ${ }^{6}$.

The contents of this paper are as follows:

(1) The wind pressure coefficient is required to calculate the ventilation rate. Therefore, the wind tunnel tests are done to obtain the relation between the wind pressure coefficient and the wind direction or the building volume ratio.

(2) The ASHRAE's SET*, the Standard New Effective Temperature ${ }^{7}$, is used for the evaluation of thermal comfort. Psychological experiments on comfort sensation are carried out to obtain the relation between the human comfort and the SET* in a naturally ventilated environment.

( 3 ) The thermal performance of a ventilated dwelling unit and an unventilated one is simulated by the program called "PSSP" (Passive System Simulation Program) ${ }^{8) \sim 11}$. Energy savings of natural ventilation are estimated in terms of heat extraction for the cooling of dwelling units. Sapporo, Tokyo and Kagoshima are selected to examine the energy saving effects regionally.

Nomenclature

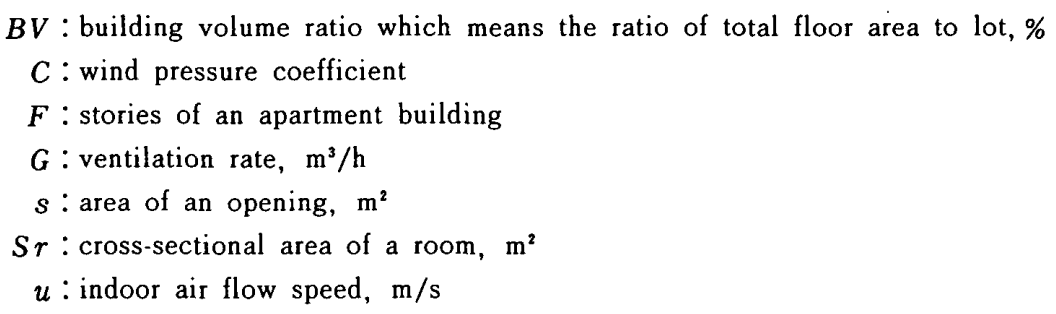

*1) Graduate Student, Kyushu Univ.

*2) Professor, Kyushu Univ., Dr. Eng.

*3) Assoc. Professor, Kyushu Univ., Dr. Eng.

*4) Professor, Kyushu Institute of Design, Dr. Eng.

*5) Professor, Kyushu Sangyo Univ., Dr. Eng.

*6) Assistant Professor, Ohita Univ.

*7) JSPS Fellowships for Japaness Junior Scientists, Kyushu Univ., Dr. Eng. (Manuscript received April 10, 1987) 
$V:$ wind speed, $\mathrm{m} / \mathrm{s}$

$V_{\infty}:$ free-stream speed in the windtunnel, $\mathrm{m} / \mathrm{s}$

$Z$ : height from the plane of the wind tunnel, mm

$\theta$ : orientation of a building from the south, degree

Subscript $W, L$ : windward and leeward, respectively.

\section{Wind Tunnel Tests}

The wind tunnel tests are carried out to obtain the
Table 1 Arrangements of buildings

\begin{tabular}{|c|c|c|c|c|c|c|}
\hline$\underset{\text { (stories) }}{\mathrm{F}}$ & $\begin{array}{l}\text { B V } \\
(\%)\end{array}$ & $\underset{(m)}{D}$ & $\underset{(\mathrm{m})}{\mathrm{H}}$ & $(\stackrel{\theta}{*})$ & & \\
\hline $\begin{array}{l}5 \\
5\end{array}$ & $\begin{array}{r}0 \\
25\end{array}$ & $\overline{123}$ & $\begin{array}{l}15 \\
15\end{array}$ & $\begin{array}{l}0 \\
0\end{array}$ & & \\
\hline 5 & $\begin{array}{l}20 \\
50\end{array}$ & 57 & 15 & 0 & $\mathrm{H}$ & \\
\hline 5 & 75 & 34 & 15 & 0 & & \\
\hline 5 & 100 & 23 & 15 & 0 & $60 \mathrm{~m}$ & $\overrightarrow{30 m}$ \\
\hline $\begin{array}{r}5 \\
10\end{array}$ & $\begin{array}{l}50 \\
50\end{array}$ & $\begin{array}{r}57 \\
123\end{array}$ & $\begin{array}{l}15 \\
30\end{array}$ & $\begin{array}{r}45 \\
0\end{array}$ & & \\
\hline
\end{tabular}

wind pressure coefficients of windward and leeward wall surfaces, relating to the building volume ratio, $B V$, stories of building, $F$, and wind direction. The arrangements of model buildings are shown in Table 1. The models are scaled in $1 / 400$.

The building volume ratios are changed with the longitudinal interval, $D$. Two kinds of model height are tested at the building volume ratio of $50 \%$. The wind tunnel used in the tests has a cross-sectional area of $1.5 \mathrm{~m}$ by $1.5 \mathrm{~m}$, with a test length of $4.6 \mathrm{~m}$. The free-stream speed $V_{\infty}$ is about $8 \mathrm{~m} / \mathrm{s}$. The models in the wind tunnel can be seen in Fig. 1. To produce a wind speed profile similar to that of the natural wind in the urban area, a screen is fixed at the outlet of the wind tunnel ${ }^{12)}$. The wind speed profile of $3 \mathrm{~m}$ downstream from the outlet is shown in Fig. 2 . The influence of the models on the mean wind speed is reduced above a height of $0.25 \mathrm{~m}$ which is equivalent to $100 \mathrm{~m}$ in field scale. Therefore, the wind speed at a height of $0.25 \mathrm{~m}$ is used as the reference speed. To avoid the blocking effect, the model blockage is limited up to $5 \%{ }^{13)}$.

The relation between the wind pressure coefficient and the building volume ratio, $B V$, is shown in Fig. 3. As $B V$ increases from $0 \%$ to $25 \%$, the absolute values of the wind pressure coefficient decrease significantly, while they decrease slowly in the case that $B V$ is over $25 \%$.

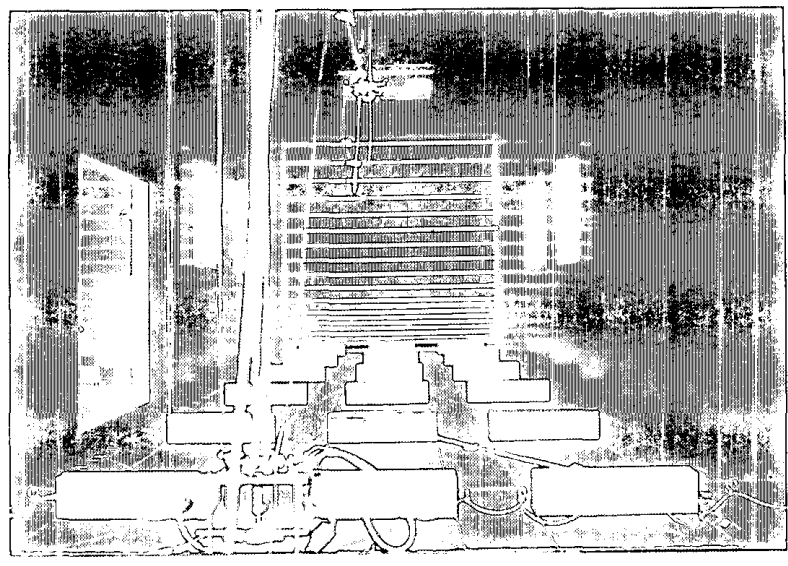

Fig. 1 Outline of the wind tunnel tests

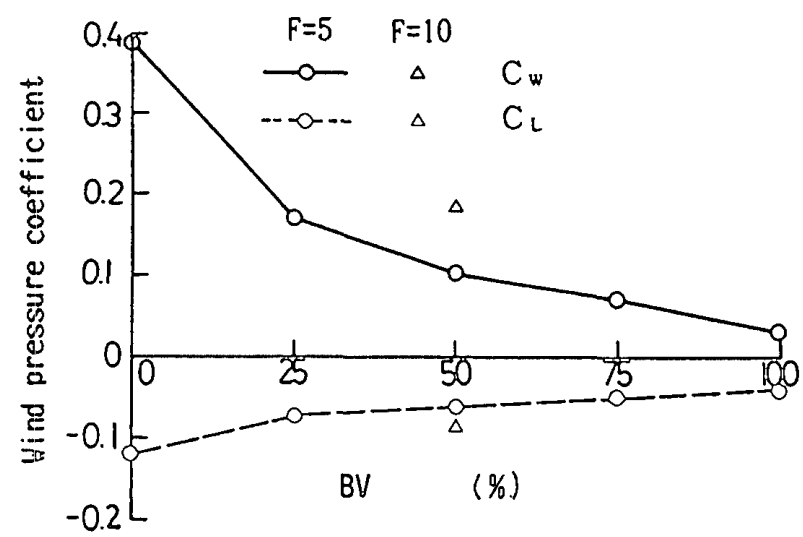

Fig. 3 Relation between the wind pressure coefficients and the building volume ratio (wind direction $=0^{\circ}$ )

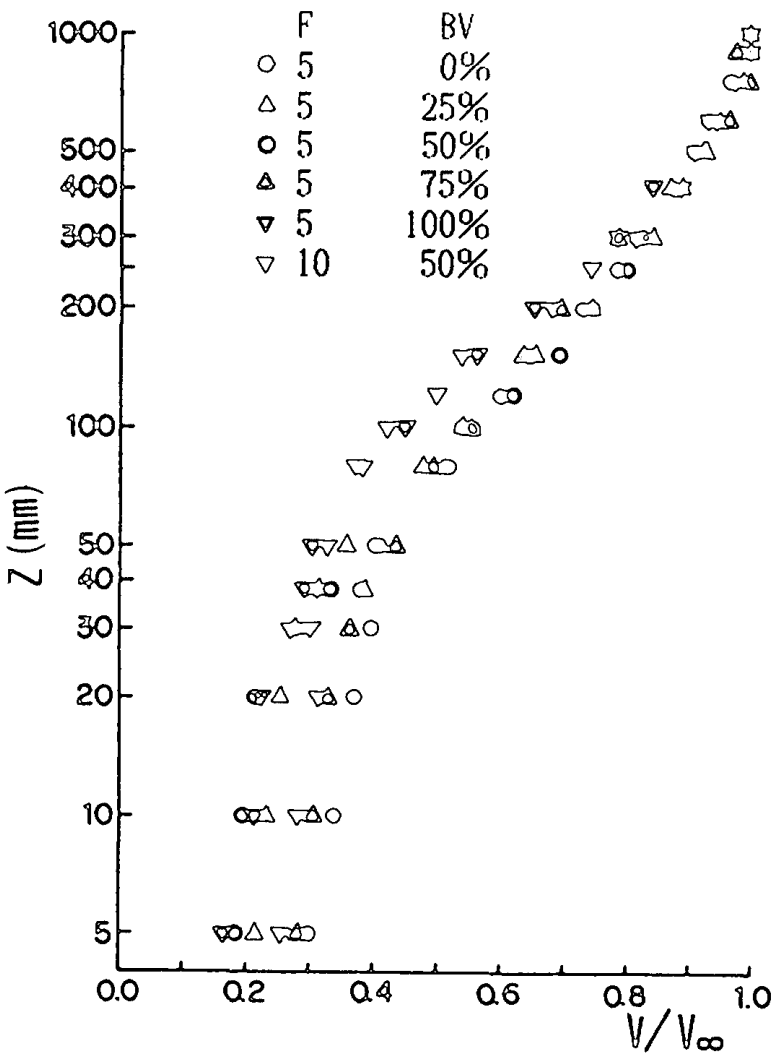

Fig. 2 Profiles of mean wind speed at $3 \mathrm{~m}$ downstream from the outlet in the wind tunnel 
Fig. 4 shows the change of the wind pressure coefficient to the wind direction at $B V$ of $50 \%$. The pressure difference between the windward and the leeward changes little if the wind direction is below $60^{\circ}$, but it decreases evidently over $60^{\circ}$.

All of the wind pressure coefficients mentioned above are the average values of the measurement points on the windward or leeward walls of the model building.

\section{Psychological Experiments on Thermal Comfort Sensation}

The indoor thermal environment must be evaluated inclusively by air temperature, humidity, radiative temperature and air flow speed. The SET*, the Standard New Effective Temperature is adopted as the overall index

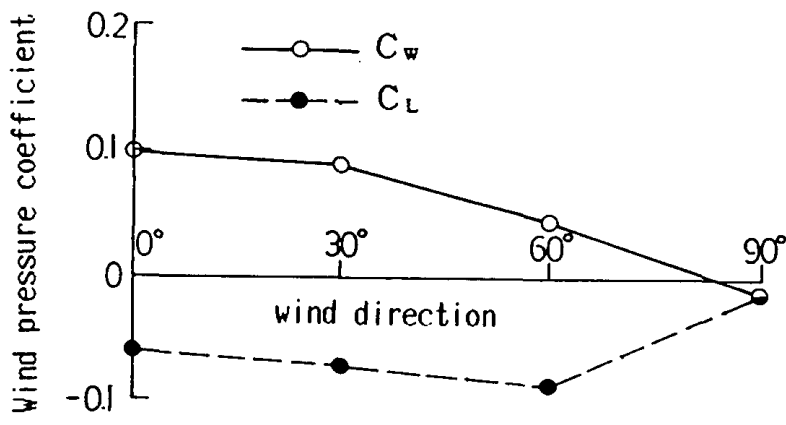

Fig. 4 Relation between wind pressure coefficient and wind direction $(B V=50 \%, F=5)$

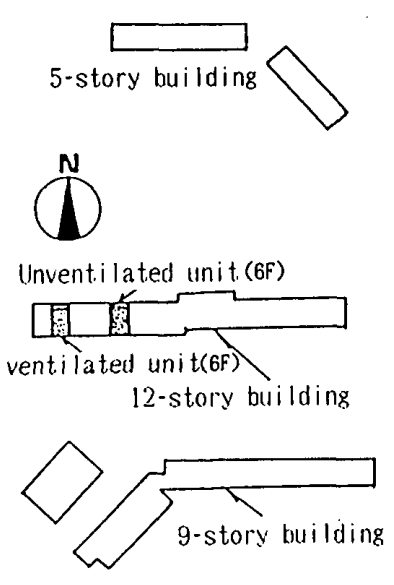

(a) location of the units

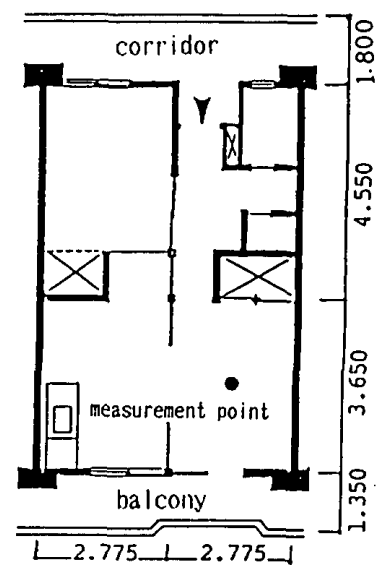

(b) plan of the unit
Fig. 5 Location and plan of dwelling units for the psychological experiments

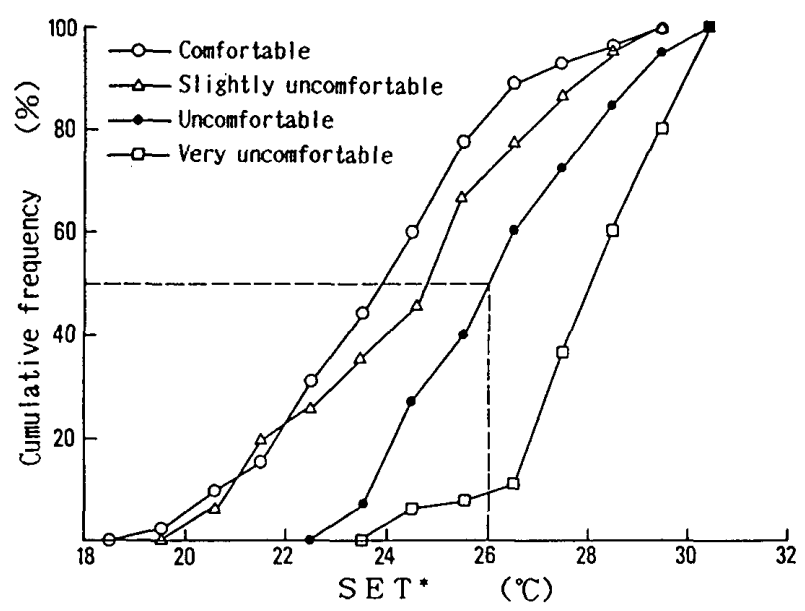

Fig. 6 Cumulative frequencies of the $\mathrm{SET}^{*}$ for comfort sensation votes

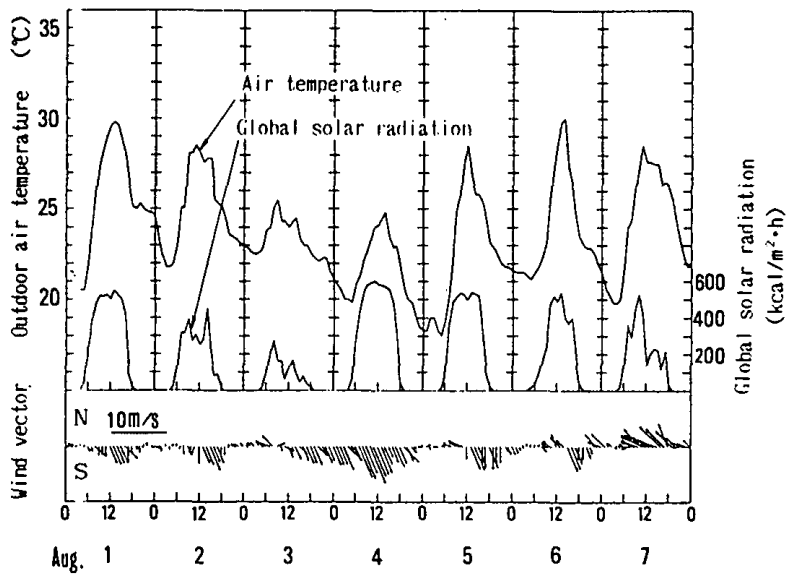

(a) Sapporo

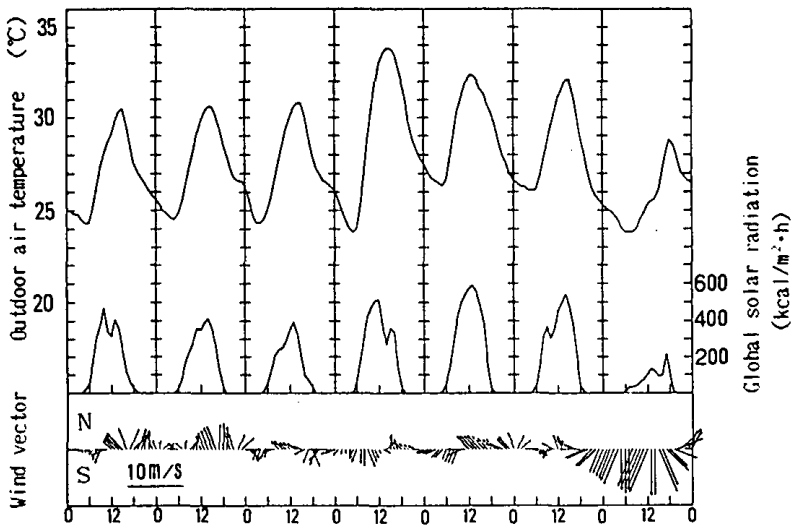

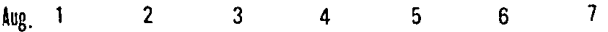

(h) Toksyo

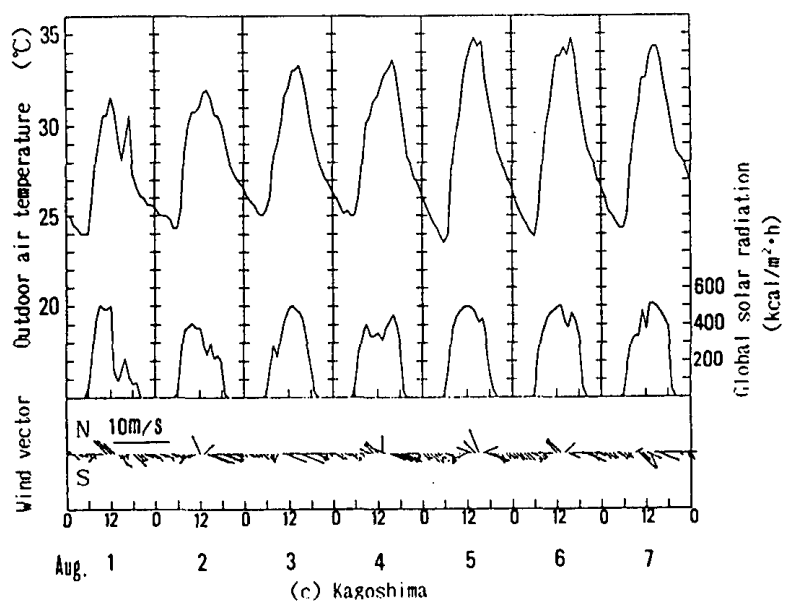

Fig. 7 The Standard Weather Data of calculation term 
of the thermal sensation here. The SET includes all the environmental and human thermal elements, therefore it can be adapted to any conditions.

In order to make clear the relation between the comfort sensation and the SET*, the psychological experiments are conducted in the naturally ventilated dwelling unit on the 6th floor of the 12 -story building as shown in Fig. $5^{14)}$. There are some studies on the thermal sensation on the artificially ventilated condition ${ }^{15)}$, however it is difficult to make a turbulent air flow of which turbulent scale and frequency range widely as natural wind. On the other hand, there are few studies on the naturally ventilated condition. Therefore, the experiments in the naturally ventilated room are done. The experiments are composed of 32 runs in total, using 4 males and 4 females subjects in college age. In a run of the experiment, a subject clothed in 0.3 clo is sedentary in 90 minutes, facing to the windward in a ventilated room after 30 minute rest in an unventilated room. The subjects' votes of comfort sensation are voted on 4-category scale by pushing vote buttons. At the same time, air temperature, relative humidity, globe temperature and wind speed are recorded.

The cumulative frequency distributions of the SET for the 4 levels of comfort sensation are depicted in Fig. 6 . In a viewpoint of energy savings, the median of the SET of a category "uncomfortable" is assumed as the tolerable limit of the indoor thermal environment. That value of the $\mathrm{SET}^{*}$ is $26^{\circ} \mathrm{C}$.

\section{Energy Saving Effects of Cross-ventilation}

To discuss the utilization of natural ventilation regionally, Sapporo, Tokyo and Kagoshima are selected. The Standard Weather Data ${ }^{16)}$ of the above mentioned cities through Aug. 1-7, considered to be typical summer days, are shown in Fig. 7. Fig. 8 shows the wind roses and the wind speed frequency distributions in this term. In Tokyo, the wind direction at night is different from that in the daytime, which is considered to be the influence of the land and sea breeze.

The PSSP is used to predict the indoor thermal environment. It can calculate dry-bulb temperature, mean radiant temperature, relative humidity, ventilation rate and air-conditioning load. The simulated results by the PSSP are
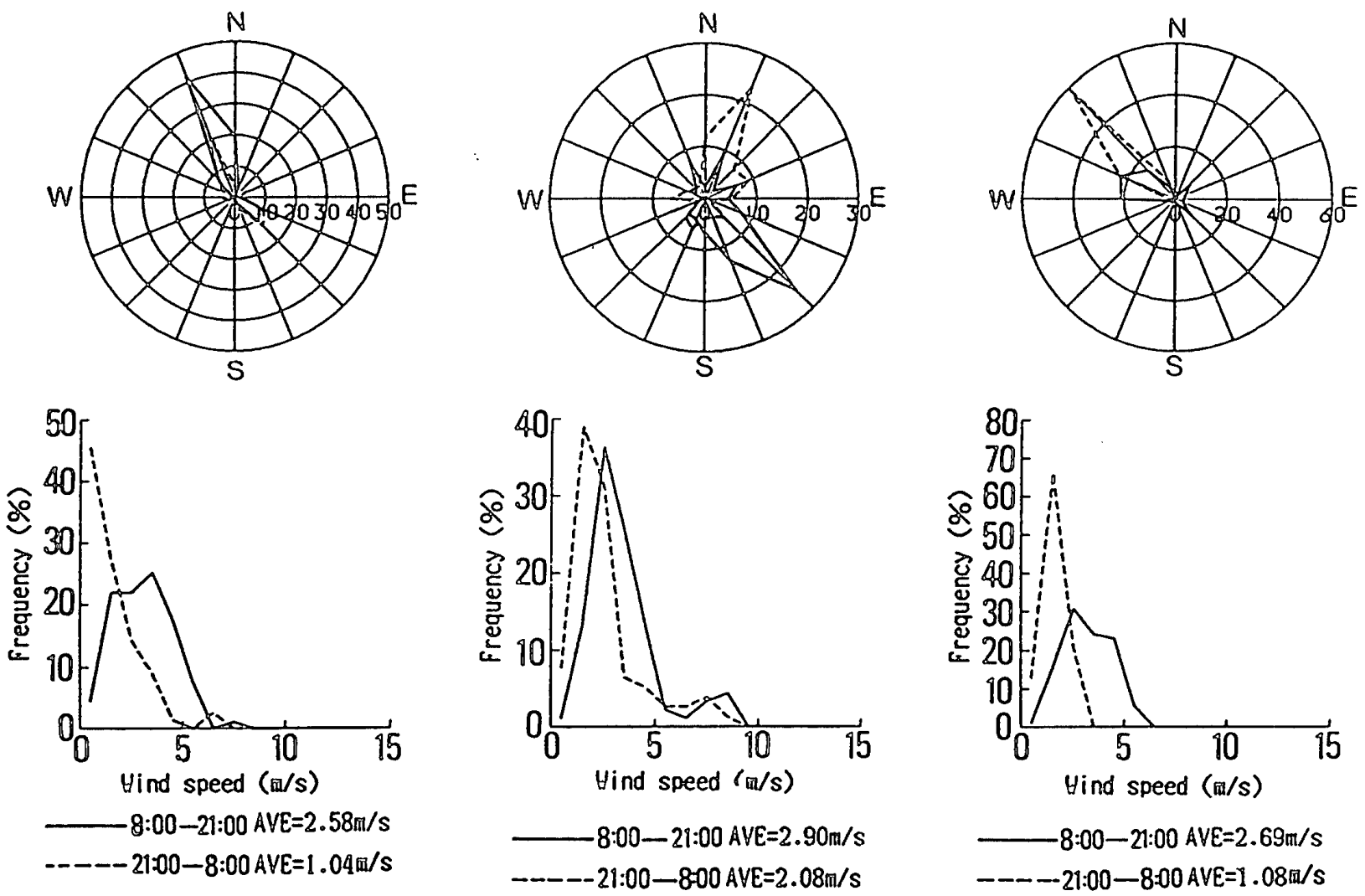

(a) Sapporo

(b) Tokyo

(c) Kagoshima

Fig. 8 Wind roses and wind speed frequencies of the Standard Weather Data ( $1 \sim 7$, August) 
compared with the measured results as shown in Fig. 9 (a), (b) and (c). These data are measured and simulated in the dwelling units shown in Fig. 5. The simulated values agree with the measured ones fairly well.

The amount of ventilation per hour, $G$ is calculated by the PSSP. Considering the air flow distribution in a ventilated unit ${ }^{17)}$, the air flow speed in the middle part of the room, $u$, is calculated by

$$
u=2 * G /(3600 * S r) \quad(\mathrm{m} / \mathrm{s}) \text {. }
$$

The dwelling unit shown in Fig. 10 is selected to examine the energy saving effects of natural ventilation in summer by the thermal performance simulations. It is supposed to be on the 3rd floor of a 5 -story apartment building

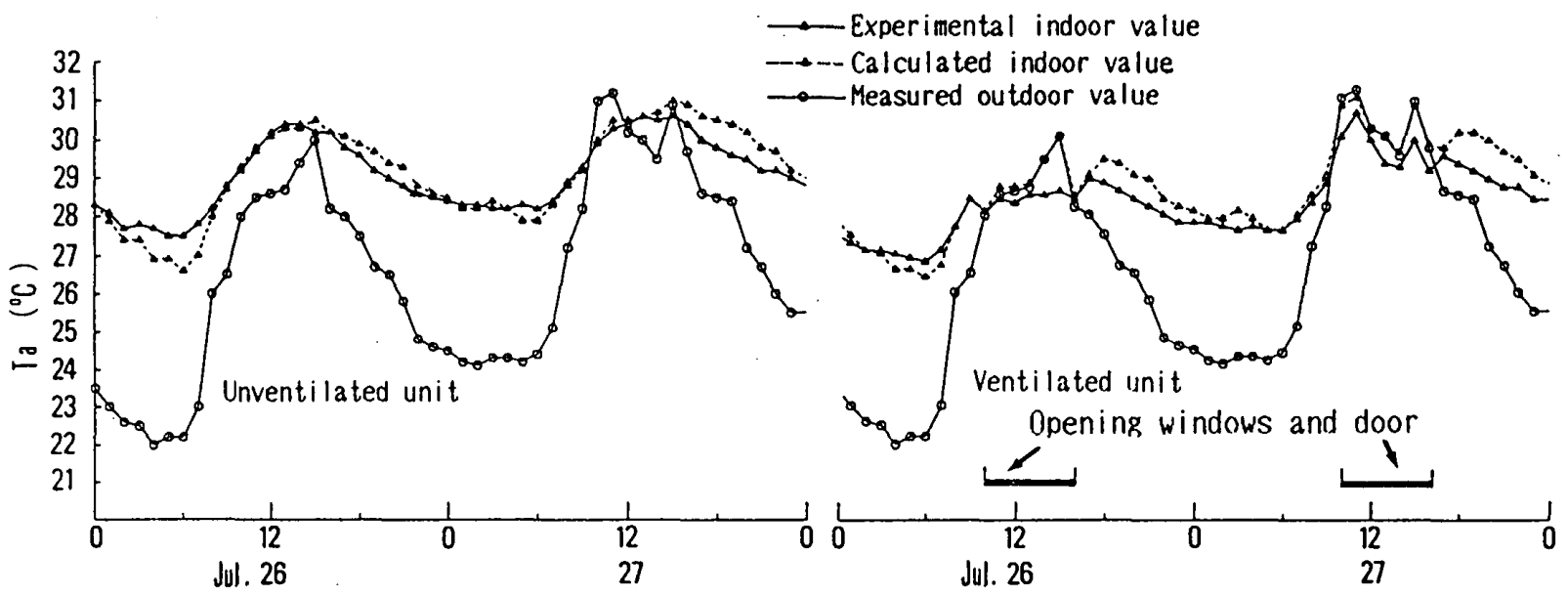

(a) indoor and outdoor air temperature

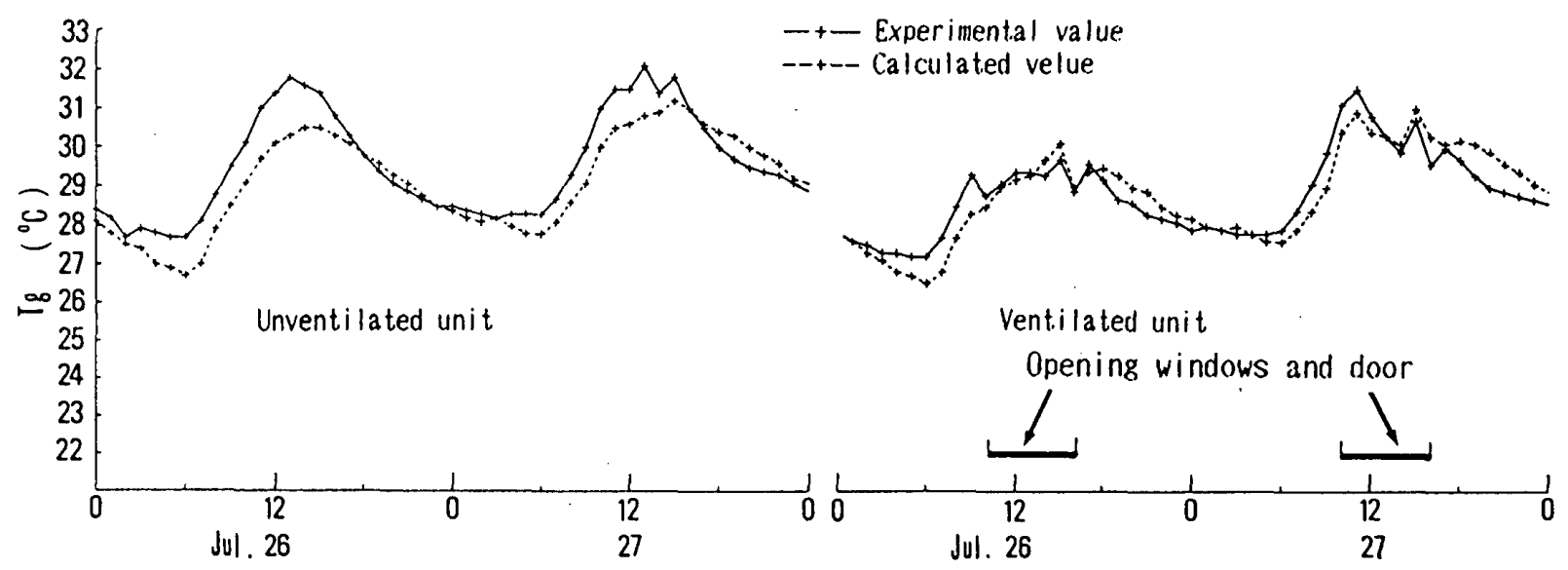

(b) globe temperature

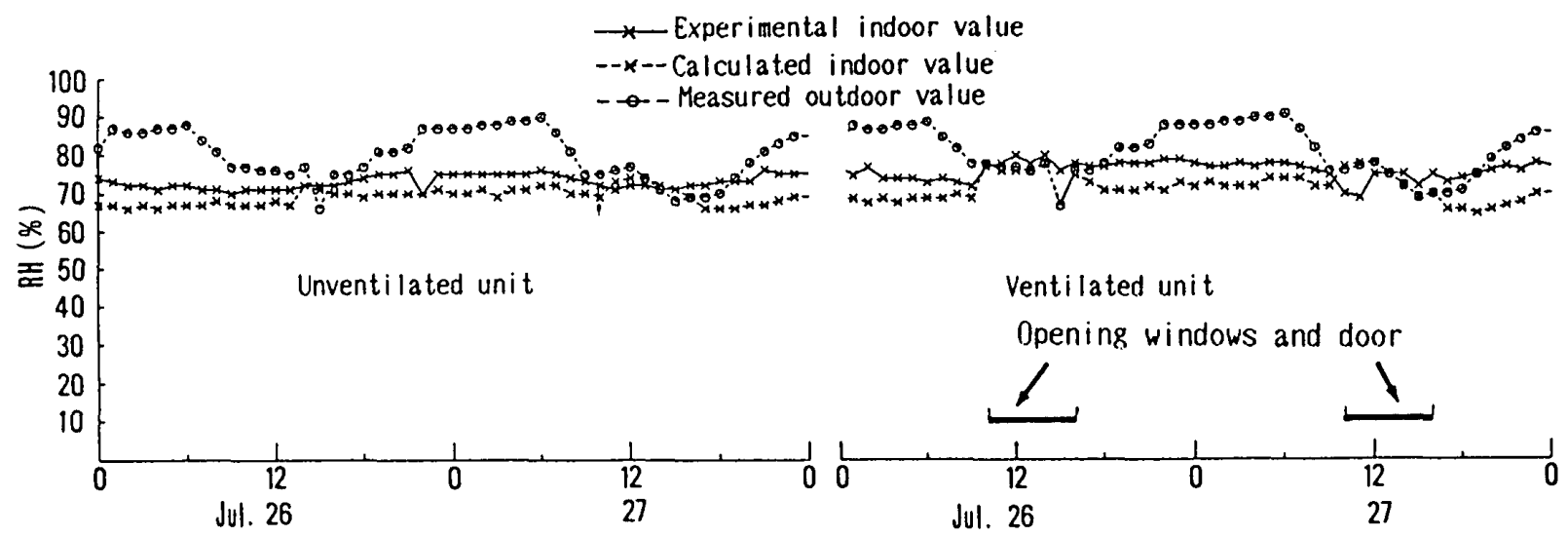

(c) relative humidity

Fig. 9 Comparisons of calculated indoor air temperature, globe temperature and relative humidity with experimental ones 


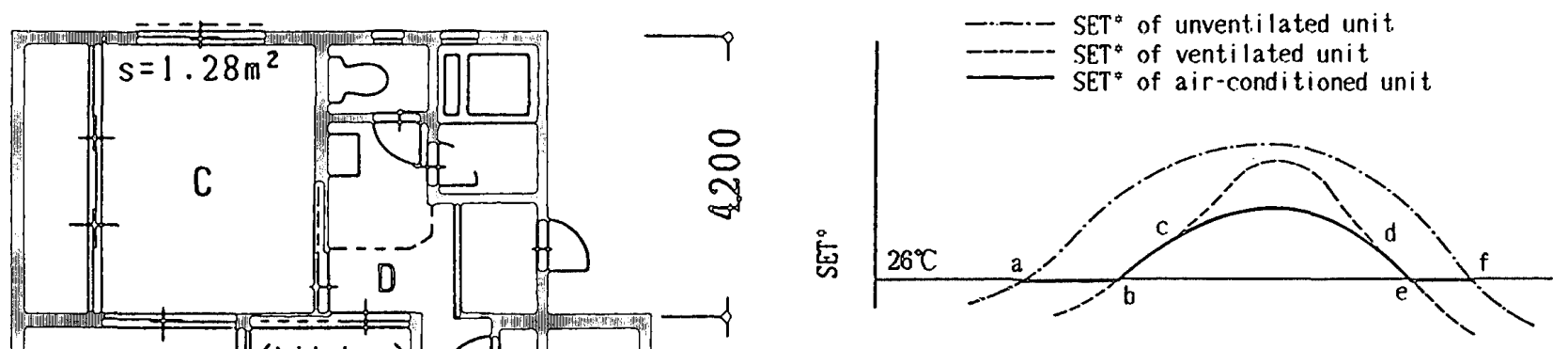

Fig. 11 Procedure to control the air-conditioner by the SET
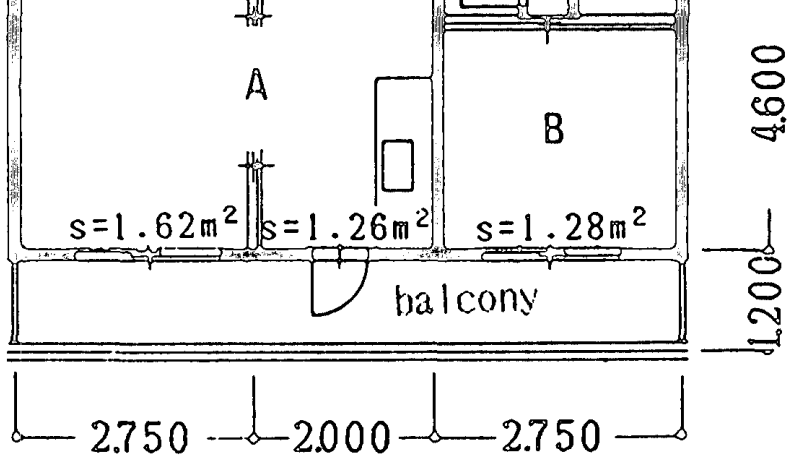

Fig.40 Plan of the dwelling unit for energy saving simulations

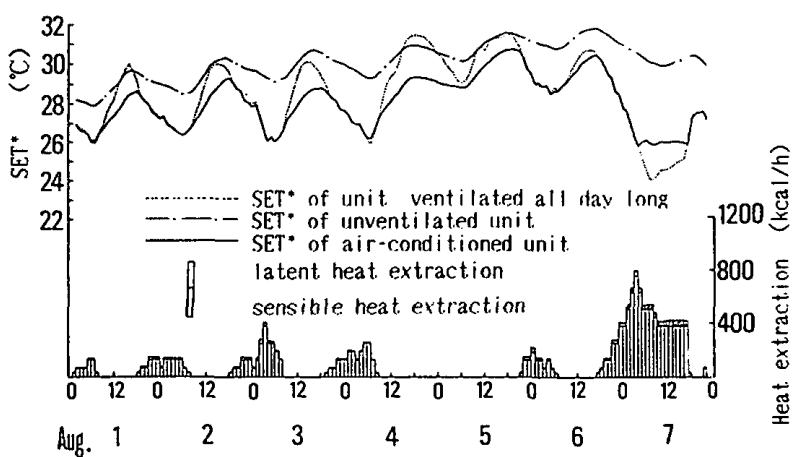

Fig. 12 Fluctution of the SET $\mathrm{S}$ in Room $\mathrm{A}$ and heat extraction of air-conditioned Room A (Tokyo. $B V=50 \%, \theta=0^{\circ}$, $F=5$ )

or the 6 th floor of a 10 -story one. The floor area of the unit is about $62 \mathrm{~m}^{2}$, and the unit is divided into 4 rooms. The unit consists of $20 \mathrm{~cm}$ concrete walls, wooden partitions, normal pane windows, interior doors (wooden doors, or Fusuma in Japanese) and exterior steel doors. Only Room A which is a living room and kitchen is equipped with a room air-conditioner, and its outlet air is supposed to be maintained constantly $15^{\circ} \mathrm{C}$ of temperature and $90 \%$ of relative humidity. In the case that natural ventilation is utilized, the windows, the exterior door at the balcony and the Fusuma doors are opened. On the contrary, all of the windows and doors are closed in the case of the unventilated unit. To simplify the analysis, there are no curtains or blinds at the windows and no generated heat from occupants, equipment and lights.

The procedure to control the air-conditioner of the unventilated unit is shown in Fig. 11. The basic concept to estimate the energy saving effects by natural ventilation is to acquire the heat extraction of the Room $A$ in the unventilated unit whose air conditioner keeps its $\mathrm{SET}^{*}$ as same as that of the room $\mathrm{A}$ in the naturally ventilated unit ( $b \sim c$ and $d \sim e$ in Fig. 11). But it seems to be unnecessary to cool extremely the unventilated unit to agree both the $\mathrm{SET}^{*} \mathrm{~s}$, if the SET of the ventilated unit is below a certain degree $\left(\mathrm{a} \sim \mathrm{b}\right.$ and $\mathrm{e} \sim \mathrm{f}$ in Fig. 11). Therefore, $26^{\circ} \mathrm{C}$ of the SET is adopted as the tolerable limit which is shown in Chapter 3. On the other hand, it is also unnecessary to warm the unventilated unit in the case that the SET is lower than that of the ventilated unit (c d in Fig. 11).

All of the simulations mentioned below are carried out during the first 7 days of August. The clothing and the activity level in the SET calculation is supposed to be 0.4 clo and 1.2 met respectively, and the wind pressure coefficients shown in Chapter 2 are applied to the simulations. Fig. 12 shows the SET ${ }^{*}$ of 3 different units and the heat extraction in Tokyo at the building volume ratio of $50 \%$. As the openings of the ventilated unit are opened all day long, its SET is generally lower and more variable than that of the unventilated unit where the air leakage through cracks on the windows and doors is taken into account. As for the air-conditioned unit, its SET fluctuation is different from both the ventilated and unventilated, and its heat extraction is large in the night but almost zero in the daytime because of the night cool heat storage.

The daily average amount of heat extraction in the unventilated and air-conditioned unit is offered as the value defining the energy savings by the utilization of natural ventilation. The relation between the energy savings and the building volume ratio, at the 3 rd floor of the 5-story apartment building facing to the south, is shown as to 3 cities in Fig. 13. In Sapporo, the SET of the unventilated unit is often lower than $26^{\circ} \mathrm{C}$, the value of energy savings is 


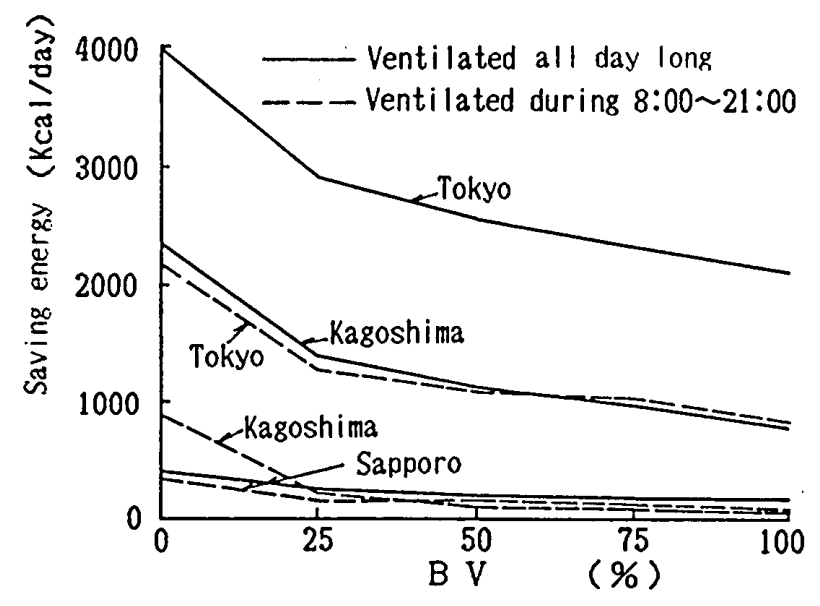

Fig. 13 Influence of the building volume ratio and the ventilating pattern on energy savings $\left(F=5, \theta=0^{\circ}\right)$

consequently very small. Though Kagoshima is hotter than Tokyo in the concerned duration shown previously in Fig. 7, Kagoshima is less energy saving than Tokyo by natural ventilation. This is because the outdoor air is so hot and the outdoor wind from the south is so weak in Kagoshima that the SET* of the ventilated unit is relatively high and the SET* difference between the ventilated and unventilated is small in comparison with Tokyo. Fig. 13 also indicates that the ventilation all day long is more effective than ventilation only during the daytime.

Next, the influence of the building orientation on the energy savings is investigated. The energy savings of 3 kinds of orientation at the building volume ratio of $50 \%$ are shown in Fig. 14. If the building volume ratio is the same, the higher building will have larger effects of energy savings because of the increase of the wind pressure as shown in Fig. 3. The energy savings of the units oriented to $45^{\circ} \mathrm{E}$ or $45^{\circ} \mathrm{W}$ are large in comparison with that of the unit oriented to the south. There are few differences of the SET*s among the ventilated units but as for the unventilated, the SET*s in the units oriented to $45^{\circ} \mathrm{E}$ or $45^{\circ} \mathrm{W}$ are higher than that in the unit oriented to the south as shown in Fig. 15.

\section{Conclusions}

This study indicates quantitatively the effects of wind-induced cross-ventilation on energy savings in summer. The main results are as follows:

1) The regional characteristics of climate affect the energy savings by natural ventilation.

2) The energy saving effects of natural ventilation all day long are larger than that of natural ventilation only during the daytime.

3) The saving energy by natural ventilation decreases according to the increase of the building volume ratio.

4) A 10-story building has larger effects of energy saving by natural ventilation than a 5 -story building. Though the energy savings by natural ventilation of the buildings oriented to $45^{\circ} \mathrm{E}$ or $45^{\circ} \mathrm{W}$ are larger than that of the building oriented to the south, the SET*s in ventilated rooms change little by the orientation of buildings.

\section{Acknowledgment}

The wind tunnel tests were supported by Mr. S. Nagano and Mr. A. Morikawa. Their support is gratefully acknowledged.

This study participates in the special project research on natural energy (complex use of natural energy, the head researcher is Professor K. Kimura, Waseda University) under the grant in aid of scientific research of the Ministry of 
Education, Science and Culture, Japan.

\section{References}

1) Katayama, T., Ishii, A., Tsutsumi, J., et al. : Cross-Ventilation by Natural Wind through Apartment Houses and Air Flow around Them, Journal of Wind Engineering, No. 18 (1984), pp.11-19.

2) Ishii, A., Katayama, T., et al. : Estimation of Thermal Environment in a Room with Cross-Ventilation by PMV (Predicted Mean Vote), Transaction of A. I. J., No. 360 (1986), pp. 12-18.

3) Ishii, A., Katayama, T. et al. : Measurements of Air Flow by Cross-Ventilation and Its Effect on Thermal Comfort in Apartment Houses, Transaction of Environment Engineering in Architecture of A. I. J. (1984), pp.69-72.

4) Nagano, S., Katayama, T. et al. : Complax Use of Wind and Solar Radiation for Various Types of Houses, Summaries of Technical Papers of Annual Meeting of A. I. J. (1984), pp. 747-748.

5) Chandra, S. and Kerestecioglu, A. A. : Heat Transfer in Naturally Ventilated Rooms : Data from Full-scale Measurements, ASHRAE Transaction (1984), pp. 211-225.

6) Kammerud, R. et al. : Ventilation Cooling of Residential Buildings, ASHRAE Transaction (1984), pp. 226-238.

7) Gagge, A.P., Nishi, Y. and Nevins, R.G. : The Role of Clothing in Meeting FEA Energy Conservation Guidelines, ASHRAE Transaction (1976), pp. 234-247.

8) Urano, Y., Watanabe, T. and Hayashi, T. : An Analysis of Room Temperature Considering Radiation Heat Transfer, Summaries of Technical Papers of Annual Meeting of A.I. J. (1982), pp.697-698.

9) Urano, Y., and Watanabe, T. : An Analysis of Multi-layer Wall Heat Transfer by State Transition Matrix (Part 1), Transaction of A. I. J., No. 311 (1982), pp.97-111.

10) Hayashi, T., Urano, Y., Watanabe, T. and Ryu, Y. : Sensitivity Analysis of Transient Room Temperature and Air-conditioning Loads, Transaction of Environmental Engineering in Architecture of A.I. J. (1983), pp.95-112.

11) Hayashi, T., et al. : Study on Passive Cooling of Dwelling Houses by Using the Heat of Earth, Summaries of Technical Papers of Annual Mecting, Kyushu Chapter of A. I. J. (1987), pp. 165-168.

12) Nishida, M., Katayama, T., et al. : Simulation of Power Law Profile by Interval Variable Screen in a Short Working-Section Wind Tunnel, Transaction of Environmental Engineering in Architecture of A.I.J., No.5 (1983), pp. 201-206.

13) Shoda, T., Murakami, S. et al. : The Apparatus of wind Tunnel Tests on Air Flow Surrounding Buildings, Transaction of A. I. J., No. 232 (1975), pp. 109-118.

14) Sakakibara, N., Ishii, A., Katayama, T, et al. : Experimental Research on the Influence of Ventilation on Thermal Sensation, Summaries of Technical Papers of Annual Meeting, Kyushu Chapter of A. I. J. (1986), pp. 27-28.

15) Nakashima, A. : Thermal Physiology, Rikogakusha (1981), pp. 66-67.

16) Matsuo, Y., et al. : Guide to Unsteady Heat Load Calculation of Air-conditioning Equipment, J. B. E. A. (1980), pp 131-136.

17) Ishii, Y., Katayama, T., et al. : A Study of Wind Tunnel Tests on Ventilation, Summaries of Technical Papers of Annual Meeting of A.I.J. (1986), pp. 313-314. 


\section{住宅における通風の省エネルギー効果に関する研究（梗概）}

\section{1. 緒 言}

夏季の気候が蒸暑な日本の住宅では, 自然通風は古く から広く利用されてきた対暑方法である。しかし，時間 的に変動の激しい自然風がもたらす気流感と清涼感それ に伴う快適感など，人体に対する温熱勃果を考慮に入れ て，通風の省エネルギー効果を算定した例はいまだ少な いようである。

本稿は，集合住宅を対象として通風の省エネルギー効 果を定量的に解析し，住棟の形状と配列，地域の気候特 性および生活方式（空の開閉）との関係を明らかにしよ とするものである。まず壁面の風圧係数に関する風洞模 型実験を行い，換気・通風量および室温などの算定に使 用する。次に通風時の温熱感覚に関し，被験者を用いた 申告実験を行い，室内熱環境のレベルを設定する。

以上の結果を用いて室内熱環境の解析を行い, 気候特 性を考慮した通風の省エネルギー量と住棟配置との関係 を求める。

\section{2. 風洞模型実験}

室内の換気・通風量は住棟の形状, 容積率および方位 などに左右される。これら住棟配置計画上の諸要素と住 棟の風上および風下壁面の風圧係数との関係を調べるた めに縮尺 $1 / 400$ の模型を規則的に配列した住棟群につい て風洞実験を行う。住棟配列の条件を Table 1 のごとく 設定する。住棟前後の間隔 $D$ を変化させて容積率を定 める。実験の状況および模型配置の状態を Fig. 1 に示 す。風洞の吹き出し口には, 自然風との相似を考虑し, 高さ方向に間隔の異なるスクリーンを設置する。スク

*1) 九州大学 大学院生

*2）九州大学 教授・工博

*3）九州大学 助教授・ 工博

*4）九州芸術工科大学 教授・工博

*5）九州産業大学 教授. 工博

*6）大分大学 講師

*7) 九州大学 日本学術振興会特別研究員 - 工博 (昭和 62 年 4 月 10 日原稿受理)

$\begin{array}{lllll}\text { 正会員 } & \text { 張 } & & \text { 晴 } & \text { 原*1) } \\ \text { 正会員 } & \text { 片 } & \text { 山 } & \text { 忠 } & 久^{* 21} \\ \text { 正会員 } & \text { 林 } & & \text { 徹 } & \text { 夫*3) }^{* 3} \\ \text { 正会員 } & \text { 石 } & \text { 井 } & \text { 昭 } & \text { 夫*4) }^{*} \\ \text { 正会員 } & \text { 西 } & \text { 田 } & & \text { 勝*5) } \\ \text { 正会員 } & \text { 榊 } & \text { 原 } & \text { 典 } & \text { 子*6) } \\ \text { 正会員 } & \text { 堤 } & & \text { 純一 郎*7) }\end{array}$

リーンの直後から模型を設置した際の下流約 $3 \mathrm{~m}$ の位 置における平均風速垂直分布を Fig. 2 に示す。 $Z=250$ $\mathrm{mm}$ 以上の高さで平均風速に対する模型配列の影響は小 さくなる。したがって実際の高さ $100 \mathrm{~m}$ に相当するこ の高さの風速を基準として壁面の風圧係数を算出する。

風向が住棟の主壁面に直角な場合の風圧係数之容積率 との関係を Fig. 3 に示す。風圧係数の値は妻側を除く 中間階の平均である。容積率が $0 \%$ (独立住棟) から $25 \%$ に上がると，風圧係数の絶対值は著しく低下する が, それ以後の容積率の増加に対する風圧係数の絶対値 の低下は緩やかである。容積率 $50 \%$ において階数を 5 階から 10 階にした場合, 風圧係数が大きくなる。容積 率が $50 \%$ の 階建住棟の場合の風向之風圧係数之の関 係を Fig. 4 に示す。風向が住棟の法線之成す角度が $60^{\circ}$ 以下のときには風上と風下壁面の風圧係数の差 $\left(C_{w}-C_{L}\right)$ は風向によってあまり変化しないが，それ 以上の風向に対しては, 風圧係数差の低下が影著である。

3. 通風時の温熱感覚に関する被匼者の申告実倹

熱環境要素および着衣, 代謝量, 発汗なざの人体側の 条件を考慮している ASHRAE の標準新有効温度 SET* を，熱環境の指標として採用する。

夏季における通風による人体の温熱感覚と標準新有効 温度 SET*との関係を明らかにするため，青年男女各 4 名の被験者により，8月上旬に各人 4 回, 計 32 回の 申告実験を行う。実験住戸は片廊下式 12 階建住棟の 6 階にある (Fig. 5(a)，(b) 参照)。被験者はまず非通風 の状態で 30 分間の椅座安静状態を経た後, 空を開放し て正面から風を受ける状態で通風環境に 90 分間暴露す る。この間, 室内の熱環境要素と同時に被験者の温熱感 覚の変化を申告スイッチを用いて記録する。快適感に関 する標準新有効温度 SET*の累積頻度分布を Fig. 6 に 示す。最適な熱環境の形成より省エネルギー効果に重点 をおき, 通風室内の快適感の限界を「不快」申告の累積 
頻度が $50 \%$ となる点と仮定すれば，Fig. 6 からその $\mathrm{SET}^{*}$ の值は $26^{\circ} \mathrm{C}$ となる。

\section{4. 通風による省エネルギー効果}

通風の省エネルギー効果は地域の気候特性により大き く左右される。ここでは，札幌，東京および鹿児島の 3 都市を対象地域とする。各都市の標準気象データから最 も代表的な夏季の気象条件とみなされる 8 月 1 7 日の 1 週間を選ぶ。その期間の気温, 水平面全天日射量, 風 向および風速をFig. 7 に示す。また，風配および風速 の頻度分布をFig. 8 に示す。

室内における気温, 湿度, グローブ温度および気流速 度を多数室の室間相互換気および室内放射伝熱を考慮し たPSSPにより予測する。Fig. 5(a) に示す 12 階建の $\mathrm{RC}$ 造の 6 階に近接する 2 つの住戸を選び, 一方を通風, 他方を非通風の状態とし，Fig. 5(b) に示す測定点の室 内空気温度, グローブ温度および室内相対湿度を計算し, 実測值と比較する。その結果を Fig. 9(a), (b) および (c) に示す。室内温度で約 $1{ }^{\circ} \mathrm{C}$, グローブ温度で約 $1.5^{\circ} \mathrm{C}$ 以内の誤差であり，よく一致するものと考えられる。

通風による省エネルギー効果のシミュレーションの対 象亡する住戸のプランを Fig. 10 に示す。住棟が 5 階建 の場合は 3 階, 10 階建の場合は 6 階にあるものとする。 住戸を DK を含めた A 室, B 室, C 室および D室に区 分し, 非通風住戸の $\mathrm{A}$ 室の $\mathrm{SET}^{*}$ を通風住戸の $\mathrm{A}$ 室の SET*に等しくするために必要な非通風室 $\mathrm{A}$ の冷房エネ ルギー量を求めて通風の省エネルギー効果を検討する。 通風時は, $\mathrm{A}, \mathrm{B}$ および C 室の外壁面の開口および各室 間の間仕切りが開放される。非通風時には外壁面の開口 および各室間の間仕切は閉鎖される。開口には, カーテ ンやブラインドは取り付けられておらず, 室内の発熱も ないものとする。

非通風 $\mathrm{A}$ 室の SET*制御による冷房の設定方法を Fig. 11 に示す。あらかじぬ通風 $\mathrm{A}$ 室の自然室温時の $\mathrm{SET}^{*}$ を求めておき, 非通風 $\mathrm{A}$ 室の SET*がそれと等 しくなるように非通風住戸A を冷房する（b〜c，dｅ）。 ただし，Fig.6に示す申告実験結果から通風A室の $\mathrm{SET}^{*}$ が $26^{\circ} \mathrm{C}$ 以下となった場合には, 非通風 $\mathrm{A}$ 室は $\mathrm{SET}^{*}$ が $26^{\circ} \mathrm{C}$ で冷房される $(\mathrm{a} \sim \mathrm{b}, \mathrm{e} \sim \mathrm{f})$ 。また, 非通 風 $\mathrm{A}$ 室の非空調時における $\mathrm{SET}^{*}$ が通風 $\mathrm{A}$ 室より低く なっても再熱は行わない $(\mathrm{c} \sim \mathrm{d})$ 。なお, 冷房は吹き出 し温度 $15^{\circ} \mathrm{C}$, 吹き出し湿度 $90 \%$ と仮定する。このよ うにして求められる冷房のエネルギー量を 8 月 1 日一 7 日の 1 週間にわたって積算し, その日平均值を通風の省
エネルギー量とする。

実際の生活パターンを考慮し, 通風住戸における開口 部の開閉は, 日中 $(8: 00 \sim 21: 00)$ 開放・夜間閉鎖之, 夜間も含めて開放する全日開放の 2 つのパターンとす る。

東京における住棟配列の容積率 $50 \%$ の全日開放した 通風住戸，冷房しない非通風住戸，冷房する非通風住戸 の SET*の計算值と冷房エネルギー量の経時変化を Fig. 12 に示す。通風住戸のSET*は非通風住戸に比較 して全体に低く，また時間的な変動が激しい。冷房する 非通風住戸の SET*も通風住戸の SET*と同じではな い。冷房のエネルギ一量は夜間に大きい。

札幌, 東京および鹿児島における通風の省エネルギー 量と容積率との関係をFig. 13 に示す。札幌では非通風 住戸においても SET*がほとんどの時間帯において $26^{\circ} \mathrm{C}$ 以下であり, 通風の省エネルギ一効果は小さい。 鹿児島では風の特性が通風に対して不利な状態であるた め通風の省エネルギー効果は東京に比較して小さい。ま た,Fig.13から，開口を夜間も開放した全日通風の省 エネルギー効果が日中開放, 夜間閉鎖の場合に比較して 大きいことがわかる。

Fig. 14 は東京および鹿児島における容積率が $50 \%$ の場合において, 住棟の方位および高さを変化させた場 合の省エネルギー量の変化を示している。住棟の高層に することによって Fig. 3 に示す風圧係数の変化により 通風の効果が大きくなる。また, Fig. 15 に示すSET* の住棟の方位による違いにより, 住棟の方位が傾いた場 合の省エネルギ一量が大きく表れる。

\section{5. 結 論}

（1）地域の気候特性が通風の省エネルギー効果に及 ぼす影響は大きい。札幌ではその効果はほとんど認めら れない。しかし，東京では開口部を全日開放した場合 $2000 \sim 4000 \mathrm{kcal} / \mathrm{day}$ の省エネルギー量に達する。

（2）全日通風の省エネルギー効果は日中のみの通風 に比較して大きい。

（3）通風の省エネルギー効果は住棟配置の容積率の 増大とともに低下する。

（4）東京および鹿児島では，住棟を高層化すること によって通風の省エネルギー効果が大きくなる。また， 住棟の方位が $45^{\circ}$ 傾いている場合, 通風の省エネルギー 量が大きくなるが, 通風室の SET*は方位によって大 きな違いはない。 